\title{
DIE GEREFORMEERDE EKUMENIESE SINODE
}

\author{
DS: A. J. VAN STADEN
}

'n Historiese Oorsig:

Die gedagte aan 'n Ekumeniese sinode van die Gereformeerde Kerke is die eerste keer in 1924 in die Sinode-sitting van die Gereformeerde Kerk van Suid-Afrika uitgespreek. Ongelukkig is daar nie dadelik aan hierdie gedagte verdere aandag gegee nie. Tenminste twee dekades sou verloop voordat verdere aandag aan hierdie gedagte gegee is. Die tweede wêreldoorlog het uitgebreek wat baie tyd verspil het. Die eenmaal uitgesproke gedagte het bly lewe en al meer posgevat, nie net in Suid-Afrika nie, maar ook in Europa en in Noord-Amerika. Na die tweede wêreldoorlog is dadelik aandag gegee aan die gedagte van 'n Ekumeniese 'Sinode'van die Gereformeerde Kerke. Die eerste vergadering is dan ook kort na die beëindiging van die tweede wêreldoorlog in Grand Rapids, Michigan belê. Die vergadering was saamgeroep in Augustus 1946. Op die vergadering was verteenwoordigers van die Gereformeerde Kerk van Suid-Afrika, die Gereformeerde Kerke van Nederland en die "Christian Reformed Church in North America". Hierdie eerste vergadering is ge-open met 'n spesiale bidstond en prediking deur Prof. L. Berkhof na aanleiding van Ef. 4. In hierdie prediking het Prof. Berkhof baie klem laat val op die eenheid van die Kerk, maar hy het duidelik aangetoon dat die eenheid van die Kerk geen uitwendige eenheid is nie, maar ' $n$ geestelike eenheid. Dit beteken egter nie dat die uitwendige eenheid verwerp word nie.

Hierdie eerste Ekumeniese sinode van die Gereformeerde Kerk was egter "foundational and preparatory in character". Dit het net die struktuur bepaal en ook die agenda vir die volgende sinode opgestel. Dit het verklaar dat die doel van die vergadering was "to give a united testimony of its faith in the midst of the world and to other churches, which need to return to the faith of the fathers". In die besprekings wat twee en "n halwe weke geduur het, het die vergadering baie aandag gegee aan die "proper name for the assembly and the ecumenical character, but also set guidelines for membership, broached the question of and relationship to other Churches and church groups (especially the Church Union Movement) and issued a ringing testimony in a reaffirmation of the fundamental victions which are embodied in the Churches' standards". 
Drie jaar later is hierdie eerste vergadering opgevolg deur 'n tweede vergadering te Amsterdam. Op hierdie vergadering was 14 kerke deur offisiële afgevaardigdes verteenwoordig en dit is nog deur omtrent 20 waarnemers en gaste bygewoon. Hierdie vergadering het baie aandag gegee aan die "Rules and Standing Orders". Die "Rules and Standing Orders" is eers in 1958 op die sitting te Potchefstroom finaal aangeneem. Hierdie vergadering van 1958 het verder ook baie aandag gegee aan o.a. (a) die Kerk en sy belydenis; (b) Die Christelike Onderwys; (c) die Eskatologie; (d) Skepping en Evolusie; (e) Die verhouding Kerk en Staat. Op hierdie vergadering is ook baie aandag gegee aan die verhouding van die Gereformeerde Ekumeniese Sinode tot ander ekumeniese liggame.

Die volgende vergadering het 4 jaar later in 1953 te Edinburgh gesit. Op hierdie vergadering is die openingswoord gespreek deur Rev. G. N. M. Collins wat o.a. die volgende gesê het: "We who meet in the membership of this Reformed Ecumenical Synod have pledged ourselves to the Reformed Faith as expressed in the great historic Confessions of our Churches. To that faith we must bear witness. Our pledges requires it; our age demands it. It has proved the correction of a wandering humanity before; in Gods hand it will prove so again".

Op hierdie vergadering is besluit dat die naam sal wees .,Die Gereformeerde Ekumeniese Sinode" (The Reformed Ecumenical Synod").

Die volgende Sinode het in 1958 te Potchefstroom gesit. Op hierdie vergadering is die behoefte aan 'n permanente Sekretaris sterk gevoel. Hy was nodig om die werk van die studie-komitees aan te help: om die agendas gereed te maak en die notules te publiseer. Ds. Gerrit Hoeksema is as deeltydse Sekretaris aangestel. Verder is die "Rules and Standing Orders" op hierdie vergadering aangeneem. Belangrike besprekings oor rasse-verhoudinge is gevoer. Prof. S. du Toit het ook die doel van die Gereformeerde Ekumeniese Sinode as volg gestel: .He declared that to justify its existence, the Synod would have to display more of the service motive than had been done before. Service and concord he saw as two inseparable aspects of the life of the Church. Our striving he said, cannot be approved by God unless the faithful render mutual assistance. Concord wiil be a reality only if all pull their weight and the yoke of Christ"

Hierdie vergadering te Potchefstroom was deur min afgevaardiges bygewoon. Na aanleiding hiervan het die President van die vergadering, Prof. S. P. van der Walt, gesê: "Brethren we may 
be only a handfull. It must be our task to fulfil our obligation in such a way that all churches pledged to the Reformed Faith can testify after our deliberations that we are still one in Jesus Christ, because we bore witness to the true Reformed standards: sola fide, sola scriptura, and sola gratia. We must bear witness to that faith in the face of all trends of relativism and accommodating methodism. We must confess that our Reformed heritage must be professed with much more virility and that spiritual declension is not due to a lack of revivalism but of good sound reformation".

Die volgende vergadering het weer in Grand Rapids gesit. Hierdie vergadering het 'n permanente sekretariaat ingestel. Die vergadering het die Interim Committee ook opdrag gegee om tussen die sinode-sittings te vergarer. Die permanente Sekretaris is opgedra om 'n gereelde publisiteitsdiens in te stel. Sedert 1964 verskyn daar dan ook maandeliks die "R.E.S. News Exchange".

Die volgende Suid-Afrikaanse Kerke is lid van die Gereformeerde Ekumeniese Sinode :-

1. Die Ned. Geref. Kerke in Suid-Afrika.

2. Die Geref. Kerk in Suid-Afrika.

3. The Church of England in South Africa.

4. En 2 Kerke van die Sudan.

Wat is nou die "Rules and Standing Orders of the Reformsd Ecumenical Synod?

\section{DIE NAAM :}

\section{"Die Gereformeerde Ekumeniese Sinode"}

Hierdie vergadering maak dus aanspraak daarop dat dit 'n sinode is. Dit wil egter nie 'n soort super-sinode wees nie. Dit wil ook nie besluite neem vir die lidkerke wat bindend sal wees nie. Dit verklaar duidelik "the decisions and deliverances of the Ecumenical Synod shall be considered advisory in character, and shall be considered binding for the respective churches only after their national Synods (or assemblies) have adopted such decisions and deliverances as their own. However, the Churches are under obligation to take such decisions under serious consideration so that there may be, as much as possible, unity in attitude and action". Die besluite "which are indisputably in full agreement with the word of God are authoritative and that is consequently not necessary to attribute judicial authority (Kerkregtelike gesag) to all decisions of Ecumenical Synods".

Die Sinode wil 'n ekumeniese sinode wees. 
In 1946 toe die Sinode die eerste keer saamgeroep is het hulle daaronder verstaan internasionaal. Die Komitee "on auth Jrity and membership" het gesê: "there is need of a more inclusive international assembly of churches which officially profess the Reformed Confessions". Daar is dus gedink aan ' $n$ internasionale Sinode. In die handelinge van die vergadering van 1949 lees ons "the church has to persue her way amid a deeply decisive disunion of the churches. In this disunion she will have to be on her guard against the pride which threatens even the life of the churches in their confession of truth; but at the same time she may not hesitate to fulfil her divine calling by confessing the truth clearly and positively and thus to pray and labor for the unity of the whole church under the one Shepherd". Hierdie betekenis het Rev. G. N. M. Collins in 1953 aan die woord ekumenies gegee. In sy sluitingsrede van daardie sitting het hy gesê: "Thus our family grows, and thus we do demonstrate to the world that ecumenism, which alone is worthy of the name, and which is conditioned in a humble submission to the sovereign authority of the word of God in faith, in service and in life".

Die woord het dus geleidelik die betekenis van „konfessionele eenheid" gekry. In 1963 het ds. Hoeksema dan ook aan die vergadering gesê: "we must be a truly ecumenical Synod, with a vision of world-wide needs and world-wide opportunities". Die Kerk moet altyd strewe daarna om hierdie eenheid te manifesteer.

Wat is nou die verhouding van hierdie Ekumeniese Sinode tot die ander ekumeniese liggame?

Op die vergadering van 1949 te Amsterdam is baie aandag aan hierdie vraag gegee. Is dit aanbevelenswaardig vir lidkerke of nie, om by die wêreldraad van kerke of die "International Council of Christian Churches" aan te sluit? Die "National Association of Evangelicals" het gevra of verteenwoordigers van hulle die vergadering van die Sinode mag bywoon. Aan hulle is toestemming gegee. 'n Versoek van die "Ecumenical Council of Churches in the Netherlands" het gevra of die tyd nie aangebreek het vir die Gereformeerde Kerke van Nederland om by die wêreldraad van Kerke aan te sluit nie. Verder het hierdie liggaam sy afgevaardigdes versoek om die lidkerke van die R.E.S. te versoek om by die wêreldraad van kerke aan te sluit. Die vergadering het toe drie Komitees benoem om verdere aandag te geen aan die ekumeniese aangeleenthede. Die een Komitee moes die aard en aktiwiteite van die ICCC en die N.A.E. (National Council of Evangelicals) nagaan. Verder moet hulle kyk of dit moontlik is om een organisasie van kerke te kry "which accept the absolute 
authority of Gods infallible word and confess and maintain the chief truths of the Christian religions".

Die tweede komitee moes 'n deeglike studie maak van die wêreldraad van kerke.

Die derde komitee moet 'n antwoord opstel vir die Ecumenical Council of Churches in the Netherlands.

In sy openingsrede aan die Sinode van 1946 het Prof. Louis Berkhof hierdie saak baie duidelik aangestip. Hy het gesê: "There is something in the idealism of the great Church Union movement of the last quarter of a century, that appeals to the Christian heart. What true child of God does not long for the day when the whole Church of God, the Church of all lands and of all ages will stand forth in perfect unity. And yet there are many children of God who cannot get enthusiastic about this movement as a whole, because they feel that it does not take sufficient account of the real root schisms, the factions, and the divisions, that now mark the beauty of the church of God and rob her testimony of a great deal of its effectiveness".

Op hierdie vergadering was daar groot meningsverskil oor hierdie aangeleentheid. Oor die ICCC het die vergadering die volgende verklaring uitgereik: "while commending many features in the statement of faith constituting the basis of the ICCC the Synod recognises in the constitution and practice of this body, certain features to which exception may be taken, and therefore does not at this time recommend membership in it, but leaves such membership to the judgement of the several churches". Die sinode het ook i.v.m. die World Evangelical Fellowship besluit om haar lidkerke nie aan te beveel om by die liggaam aan te sluit nie. Verder het die Sinode besluit om aansluiting by die wêreldraad van kerke af te keur. Daarvoor het die Sinode twee redes aangegee: (a) "The World Council of Churches actually permits essentially different interpretations of its doctrinal basis, and thus of the Christian faith. (b) The World Council of Churches represents itself as a community of faith, but is actually not this, for churches of basically divergent positions are comprised in the World Council of Churches". Verder het die Sinode besluit om die Kerke wat reeds lid van die Wêreldraad van Kerke is te vra: "to consider their position in the light of the foregoing". Die Sinode van 1958 het weer aandag aan hierdie vraagstuk gegee. Daar is toe ' $n$ komitee aangestel om die moontlikheid van aansluiting by ander ekumeniese liggame te ondersoek. Die Sinode van 1963 het toe die volgende besluit geneem: "Taking note of the fact that the Deputies of Ecumenicity have not completed their 
study, and in view of the undeniable fact that outspoken liberals are active, and in some instances prominent, in the W.C.C. and that some of its member churches knowingly tolerate and even highly honour as preachers and teachers, deniers of cardinal truths of the Christian religion, the Synod is assured that in their further study the deputies (of the Reformed Churches in the Netherlands) will do justice to the antithesis of belief and unbelief, the true Church and the false, as taught in Article 29 of the Belgic Confession and passages XXV of the Scripture as Gel. 1:8-9; \# Kor. 6:14-18, and 2 Joh. 1:10-11. Synod looks forward with great interest to the result that may be expected of further study of these deputies presuming that no further steps concerning affiliation with any ecumenical organisation will be taken by the Gereformeerde Kerken in Nederland, without consultation beforehand with the R.E.S. Hierdie vraagstuk sal seker nog dikwels op die sinode-sittings bespreek word.

\section{DIE GEREFORMEERDE EKUMENIESE SINODE EN DIE ROOMSE KERK.}

Op die tweede Vatikaanse Sinode is daar belangrike besluite geneem As gevolg van hierdie besluite het die vraag ontstaan of die Nederlandse Kerke nie hulle houding ten opsigte van die Roomse Katolieke Kerk in hersiening moet neem nie. Op hierdie vraag het die R.E.S. van 1963 die volgende antwoord gegee: "Although the later development in the Roman Catholic Church seems to have raised high expectations in some Protestant circles regarding the possibility of a reapproachment of the Churches of the Reformation and the Church of Rome, there are no decisions of the Second Vatican Council to make such expectations realistic.

Although the Roman Catholic Church shows a tendency to soften its attitude towards those who do not belong to that communion and seem to have under consideration a revaluation of the Bible in relation to tradition, yet there has not been any attempt on its part towards removing the real barriers between the churches of the Reformation and the Church of Rome, i.c. the unscriptural doctrines and practises of the Roman Catholic Church.

The Churches of the Reformation in their approach to the Roman Catholic Church and its members cannot do otherwise than to point to the infallible Word of God as the sole rule for faith and conduct, while praying that the Holy Spirit may open the eyes of the Roman Catholic Church to the sole mediatorship of 
Christ, and the truth of salvation by grace alone, as set forth in the Holy Scriptures.

The Churches of the Reformation should assiduously resist tendencies to compromise with such practices of the Church of Rome as are at variance with the centrality of Holy Scripture in the service of God and the simplicity of the New Testament worship".

Die Sinode het sy standpunt ten opsigte van die Rooms Katolieke Kerk so duidelik as moontlik gestel. (Vgl. Wêreldraad en Rome : Acta: N. Delhi bl. $17 / 18$ bl. 50).

\section{DIE BASIS WAAROP DIE R.E.S. GEGROND IS.}

Omdat die basis, doel en lidmaatskap van so besondere belang vir ons is, is dit miskien nodig dat ons hierdie punte in die woorde van die R.E.S. self gee :

Die Basis: (Vgl. Wêreldraad Evanston bl. 337). "The foundation of the Reformed Ecumenical Synod shall be the Holy Scriptures of the Old and New Testament as interpreted by the confessions of the Reformed Faith, namely, the Second Helvetic Confession, the Heidelberg Catechism, the Gallican Confession, the Belgic Confession, the Westminister Confession, the Canons of Dort, the thirty-nine Articles. It should be understood that these Scriptures in their entirety, as well as in every part thereof, are the infallible and ever-abiding Word of the living Triune God, absolutely authoritative in all matters of creed and conduct, and the Confessions of the Reformed Faith are accepted because they present the divine revealed truth, the forsaking of which has caused the deplorable decline of modern life. It has to be emphasised that only a wholehearted and consistent return to this Scriptural truth, of which the Gospel of Jesus Christ is the core and the apex, can bring salvation to mankind and effectuate the so sorely needed renewal of the world.

Because of the diversity in the forms of government of the Reformed Churches, uniformity of Church policy cannot be stressed as a fundamental requisite, except in so far as the principles of the polity are contained in the Reformed Confessions, as, for example the headship of Christ and the marks of the true Church the pure preaching of the Gospel, the Scriptural administration of the Sacraments, and the faithful exercise of discipline". 


\section{DIE DOEL.}

"The purpose for the holding of Reformed Synods shall be five-fold :

1. To advise one another regarding questions and problems of import pertaining to the spiritual welfare and the scriptural government of the Churches.

2. To confer together, as far as advisability or necessity may require, regarding missionary work of the Churches at home and abroad.

3. To strive to obtain a common course of action with respect to common problems; likewise to issue joint resolutions regarding movements, practices or dangers, when joint statements are deemed necessary.

4. To give united testimony to our common reformed faith in the midst of a world living in error and groping in darkness particularly to the many Churches which have so lamentably departed from the truth of God's Holy Word, and which are in dire need of a return to the faith of the fathers.

5. To express our precious unity in Christ and our oneness as Reformed Churches, though scattered over the earth". Hier is geen sprake van 'n super-sinode nie :

\section{LIDMAATSKAP (Vergelyk wêreldraad van Kerke)}

.Membership in the Reformed Ecumenical Synod shall be open to all denominations which profess and maintain the $\mathrm{Re}$ formed faith and which therefore subscribe to the Basis as expressed in Article II of these Rules and Standing Orders.

Delegates to all Synod meetings are expected to express their agreement with the aforementioned Basis and to give testimony to the fact that they adhere to the Confessions of the Reformed faith.

In extending invitations to membership in the Synod, the list of Churches approved by the gathering at Amsterdam in 1949, and as revised by successive meetings of the Reformed Ecumenical Synod, shall be directive".

Volgens die notule van die 1963 vergadering te Grand Rapids, V.S.A., was daar kerke verteenwoordig uit Afrika, Asië, Australië 
en New Zealand, Europa, Noord-Amerika en Suid-Amerika. Op die 1963 vergadering was die volgende kerke uit Afrika verteenwoordig:

$\begin{array}{lrc} & \text { Ledetal } & \text { Persentasie } \\ \text { 1. Church of England in South Africa } & 21,000 & 4 \% \\ \text { 2. Die Nederduitsch Gereformeerde Kerk } & 1,177,958 & 21 \% \\ \text { 3. Die Gereformeerde Kerk, Suid-Afrika } & 93,900 & 7 \% \\ \text { 4. Ekklesigar Kristi a Sudan East Benua } & 6,152 & 25 \% \\ \text { 5. Nongo U Kristu U Ken Sudan Hen Lis } & 9,991 & 25 \%\end{array}$

DIE R.E.S. EN RASSE-AANGELEENTHEID.

Die R.E.S. hiet bate aandag aan hierdie aangeleentheid gegee. Reeds die vergadering van 1946 het hierdie aangeleentheid op die agenda gehad. Op die vergadering van 1953 het die Ortodokse Presbiteriaanse Kerk van Noord-Amerika die Afrikaanse Kerke gevra of hulle die Apartheidsbeleid van die Suid-Afrikaanse regering ondersteun en indien wel hoe hulle dit versoen kry met die Bybel. Die 1953 vergadering het 'n komitee benoem "to consider racial Relationships with particular reference to racial segregation and Colour Bar". Die 1958 vergadering te Potchefstroom verklaar dat die menslike geslag ' $n$ eenheid vorm en stel ' $n$ ander kommissie aan om die saak verder te ondersoek. Die 1963 vergadering het lank en breed oor hierdie aangeleentheid gehandel en toe die volgende verklaring uitgereik.

1. "Synod warns against an incautious use of the terms "principle". It would appear that in the materials before us there are varying usages of the word. When the Synod uses the term "principle" in this context the term shall mean a regulative rule of conduct expressive of God's will as revealed in Scripture, and demanding application regardless of place, time and circumstance.

2. Synod states as its belief that God's Word does not teach either racial integration or separate racial development as universally regulative principle expressing God's will for our Christiar conduct in race relations. God's word speaks relevantly to specific racial problems but it cannot be simply assumed that every form of separate racial development is either biblical or anti-biblical, neither can it simply be assumed that every form of racial integration is either biblical or anti-biblical. The spesific and highly complex sociable relationships within each land and nation must be taken into careful account when applying the biblical principles of love and neighbourness for all men of all races and all nations. 
3. Synod urges the exercise of extreme caution in the use of scripture texts to justify specific racial policies. It is questionable, for example, whether clear statements on racial issues can be deducted from the Babel account of Genesis 10 and 11, and from the Pentecostal account of Acts 2, beyond taking note of the devisive factors which clearly do exist among men; and the necessary requirement that every man should be able to hear the gospel in his own tongue.

4. Synod declares that where members of one ethnic group or nation permanently live together with other ethnic groups or nations within the same country, all individuals, groups and nations shall be equally accorded God-given rights before God and the law, and each individual, group or nation in the exercise of Godgiven rights must not violate the God-given rights of the other individuals, groups or nations. If two or more nations or ethnic groups in the same country wish to maintain their respective identities, territorial separation between these nations or ethnic groups cannot be disapproved on the basis of principle.

5. Synod declares that where there is violation by civil government of the teachings of Gods word, it is the duty of Christians, unitedly and individually to address the necessary admonition to those in governmental authority. It is the responsibility of the Church to instruct its members in the application of God's word to every sphere of life, and where necessary, to address the government directly concerning such problems as may arise.

6. Synod declares that where young Christian Churches which have come into existence through mission effort belong to different nations, speaking different languages and having different cultures than the older Church which inaugurated mission work, it is advisable, that these Churches maintain separate assemblies up to the level of their own national synods. But the unity of tha Church of Christ, in its diversity, must further be expressed and revealed either by holding joint synodical gatherings as soon as circumstances permit, or in such organisational development as will reflect that unity as far as it is possible to do so. In this way the one Church of Christ in its universality, its unity, and its pluriformity will be progressively revealed among nations of the world".

Die groot verskil tussen die standpunt van die R.E.S. en die wêreldraad van Kerke, spring dadelik in die oog wanneer ons let op die volgende stelling van die wêreldraad van Kerke:

"Een resolutie inzake Rassen en etnische verhoudingen voorgesteld door de commissie werd met algemene stemmen aange- 
nomen. De resolutie was bedoeld als aanvulling van die principiële uitspraak van de vergadering te Evanston dat elke vorm van segregatie, gegrond op ras, huidkleur of etnische oorsprong, instryd is met het Evangelie. De resolutie vroeg aandacht voor de toenemende spanningen, maakt met dankbaarheid melding van het onuithoudbaar getuigenis van vele Christenen in moeilijke situasies en drong er op aan, dat die Kerken alom meer vastberaden zullen optreden tegen „segregatie die gegrond is op ras, huidkleur of etnische oorsprong". (Kampvuur der Kerken Bls. 41)

Die Nu-Delhi vergadering van die Wêreldraad van Kerke het ook 'n boodskap aan die christene in Suid-Afrika gestuur. In die boodskap word gesê .,dat tijdens die vergadering, onze overtuiging inzake die eenheid der Kerk zijn versterkt, en de uitspraak van Cottesloe werd bekrachtigd dat niemand die in Jezus Christus gelooft, mag worden uitgesloten van enige Kerk opgrond van ras of huidkleur. De boodschap bevestigde opnieuw het standpunt inzake het rassenvraagstuk, ingenomen door de vergadering van Evanston, en verklaarde dat in naam van Christus velen zich in Zuid-Afrika zich betrokken werden in de strijd voor uitbanning van rassenscheiding en discriminatie". Die boodschap is met algemene stemme goedgekeur.

Die Nu-Delhi-vergadering het die teenstanders van integrasie opgeroep tot die stryd. "Het is de roeping van de Kerk daadwerkelijk na de rassengerechtigheid te streven. Christenen moeten zich niet laten binden aan een bepaalde manier van optreden, maar moeten vrij gebruik maken van verskillende middelen, verzoening, procesvoering, wetgeving, bemiddeling, protest, economische sancties en geweldlose actie, eventueel in samewerking met niet kerkelijke groepen die voor het zelfde doel werken". Verder het die Vergadering besluit: "Waar onderdrukking, discriminatie en rassescheiding heersen, moeten de Kerken zich aan de zijde van het verdrukte ras in zijn strijd voor gerechtigheid scharen. Christenen moeten bereid zijn in deze strijd leiding te geven. De revolutie is aan de gang, of wij het willen erkennen of niet; en zonder christelijke leiders kan ze op tragische wijze verkeerd gaan".

\section{INTERKERKLIKE VERHOUDINGS.}

Die Sinode van Grand Rapids V.S.A. het in 1963 die volgende veelseggende besluit geneem :

(a) "Christ commanded his church to preach the Gospel to all nations for the sake of the redemption of all the elect who are in Him united through the working of the Holy Ghost to a deeper, spiritual unity. 
(b) The teaching of the New Testament does not merely pertain to the redemption of the individual but to the solution of the nation of Israel and the nations (all nations) who are redeemed in their believers.

(c) The scriptural unity of the church of the Lord, is embedded on a niveau deeper than the natural and organisational. In its deepest essence the community of the faithful is one and universal in spite of manifold division.

(d) Notwithstanding, however, it must be manifested institutionally in ecumenic bond according to the fundamental unity of teaching, ministry and discipline. The various linguistic and cultural groups ought locally to institute their own congregations up to the national level. Separate institutionalisation is desirable as well as essential to promote the cause of Christ. It serves, inter alia, to stimulate the younger churches and to enrich the ecclesiastical life. The ecumenic bond is similarly imperative to bring to light the spiritual unity.

(e) This racial and national admixture as principle and rule in the ecclesiastical sphere must be rejected. It does not serve the cause of the church. It pleased the bond that, on the day of pentecost, every one present should hear them speaking in his own tongue the wonderful words of God".

(f) The sacrament of the Holy Communion is ministered by the Local congregation where the responsible church council supervises the admission. The Holy Communion may not be abused as a demonstration of ecumenic unity.

Dit sal miskien goed wees om net weer die standpunt van die Gereformeerde Ekumeniese Sinode insake Volksvereniging op staatkundige en kerklike terrein teenoor die van die Wêreldraad van Kerke te stel. Die Gereformeerde Ekumeniese Sinode sê: "If two or more nations or ethnic groups in the same country wisn to maintain respective identities, territorial separation between these nations or ethnic groups cannot be disapproved on the basis of principle". Terwyl die Wêreldraad van Kerke te Nu Delhi besluit het "dat elke vorm van segregasie gegrond op ras, huidkleur of etnische oorsprong in strijd is met het Evangelie" en dan maak die Wêreldraad 'n beroep op die kerke om "meer vastbesloten te zullen optreden tegen segregasie die gegrond is op ras, huidkleur of etnische oorsprong".

Verder het die vergadering besluit dat: "Alle Christelijke instellingen moeten bij huisvesting en tewerkstelling een open beleid voeren. Die wêreldraad kan geen goeie rede vind vir "ge- 
scheiden ontwikkeling" nie, en vir die wêreldraad is die uitdrukking, "gescheiden maar gelijk" in de levende werklikheid een contratictio in terminus". Daarom vind die wêreldraad dan ook dat "het nationalisme een even groot gevaar is in Amerika en Europa als in Azië en Afrika".

\section{DIE SOSIALE VERHOUDINGS.}

Oor hierdie aangeleentheid het die Gereformeerde Ekumeniese Sinode haar duidelik uitgespreek. Terwille van die duidelikheid gee ons die hele besluit:

1. "Although humanity is a unity, this does not imply that God willed a uniformity. Gen. 1. He calls into being peoples, nations and tongues, each with its own identity and nature and $\mathrm{He}$ determines the bounds of their habitations. Gen. 10 and 11 Acts $17 / 26)$. Differentiation is the natural result of the divine injunction to replenish the earth.

2. The differentiation into peoples and races with the accompanying talents, development, civilization, numbers, etc., justifies no people or race whosoever to exalt itself in pride over and against others or to abuse its power. Notwithstanding the miscellaneous differences in disposition, state and development etc., peoples and races in the same sense as individuals are of equal status before God.

3. As a result of $\sin$ these differentiations are either obliterated to the similarity of Babel (Gen. 11) or they are whetted to enmity. Concepts like individuality or kind (eiesoortigheid) and difference of kind (andersoortighede) never are static, but according to the word of God one has to distinguish between the wiping out of boundaries as a principle and an admixture causing new varieties. Hence all false craving for unity, massification and nullification out of limitations as are preached by liberalism and communism should be rejected being in conflict with scripture. It leads to the kingdom of the antichrist.

4. The propagation of the Gospel presupposes the existence of peoples (ch. the injunction relation to baptism Matth. 28:19 and Luke 24:47). Thus, Christian nations originate at the side of pagan peoples while an admixture of the two might comprise a menace to Christianity. In this sense of prohibition with regard to admixture contained in the Old still holds true for the New Testament. Admixture (or races, nations) is sinful when the christian and valuable elements in culture are endangered. It may even have disastrous results. This stands in close relation to the Scriptural 
ordinance that the spouses should be "an help meet" for each other.

5. The previous paragraphs lead to the conclusions that it is the duty of every people to preserve and safeguard its own peculiar culture, to develop it positively so as to be able to fulfil its divine cuiltural calling to the glory of God and as a blessing for the whole world.

6. The Holy Scriptures clearly teach that excessive nationalism (viz. idolisation of the nation or people) is contradictory to the Commandment of God just as cosmopolitanism and world citizenship (viz. slighting of the nation/peoples). A nationalized religion, being essentially idolisation of the nation similarly is unscriptural.

7. In their mutual relations races and peoples are subject to the same commandments of love and righteousness. Those peoples who, by the grace of God, are further developed than others are by divine and duty bound to stimulate the less developed, to obedience of God's ordinance of cultural dominion so as to bring the potentialities and calling of the latter to its full fruition. Whenever one nation is brought in the situation of wielding authority over another for the sake of maintaining law and order, it means a tremendous responsibility and positive duty of the guardian in leading the "minor" with justice and love to full independence in obedience to the laws of God".

Die Gereformeerde Ekumeniese Sinode stem nie met die wêreldraad saam as die wêreldraad sê: "It cannot approve any law against racial or ethnic intermarriage, for christian marriage involves primarily a union of two individuals before God which goes beyond the jurisdiction of the state or of culture". (Vgl. Acta 1963, Bls. 158).

As die wêreldraad sê dat die Nagmaalstafel die eenheid van die Kerk demonstreer, dan sê die Gereformeerde Ekumeniese Sinode: "The Holy Communion may not be abused as a demonstration of ecumenic unity".

Wat die eenheid van die Kerk betref sê dr. Golterman dat die wêreldraad "is een ontmoetingspunt en tracht de kerken door het onderlinge gesprek tot elkaar, uiteindelik tot organische eenheid te brengen". Die wêreldraad is "voorlopig een gespreksgemeenskap". Daarom het die wêreldraad haar oorspronklike leuse van "Wij zijn van plan bijeen te blijven" verander na "wij zijn van plan ons te verenigen". Nieteenstaande al die ontkennings streef die wêreldraad tog organisatoriese eenheid na. Teenoor die sigbare organisatoriese eenheid van die wêreldraad is die standpunt van 
die Gereformeerde Ekumeniese Sinode dat die Kerk ook een is maar daardie eenheid is 'n geestelike eenheid. In verband met hierdie aangeleentheid verklaar die 1963 vergadering "Granted the fact that the word "church" knows no plural, because there is but one Christ, one Spirit, and one flock, as it is taught irrefutably in the New Testament, no church which acknowledges its solidarity in the guilt of the disruption of Christ's church may acquiesce in the fact that Christ's boundaries of the church do not coincide with the historical drawn lines of separation. In the firm conviction that Christ's church manifests itself wherever the sprinkling of the blood of Christ and the workings of God's Spirit and Word are bound, such a church shall have to seek ways to heal the disruption of Christ's church, which is spiritually harmful and an appalling offence and stumbling-block for the world, and above all is a reproach for the name of the Lord.

Nevertheless, we must not lose sight of the view of the Scriptures that the unity of the church is a unity of rich diversity. This diversity is manifested in the local churches and in the instituting of the one christian church among many peoples. This is not a sinful condition but a normal phenomenon in this dispensation.

However, this diversity may never deteriorate into separation, wherefore the churches must constantly admonish one another and summon one another to conversion and rereformation. In that diversity, the unity which rises above national and language boundaries must be sought and maintained, also in the ecumenical context, wherever possible. But there must be constant vigilance to prevent a unity that is sought and brought about at the expense of the truth of the gospel of our Lord Jesus Christ". Die eenheid moet dus gesoek en bewaar word, maar geen eenheid ten koste van die waarheid van die Evangelie nie.

Die Gereformeerde Ekumeniese Sinode streef daarna -

(a) om ten volle lojaal en gehoorsaam te wees aan die waarheid van die Bybel;

(b) om te probeer om die ware katolisiteit van die Kerk van Christus te toon en om uitdrukking te gee aan die gemeenskap van die heiliges;

(c) dit glo dat die Bybel: "forbids worth unity at the expense of the truth and isolation at the expense of the unity".

(d) dit glo verder dat sy "must be more than a circle of churches whose gaze is turned inward and whose concern for the other churches and the world is minimized. The 
confessional unity the churches possess gives them a strength with which to pursue their task with great vigour. To an increasing degree the member churches are realizing their awkward looking calling".

\section{AANBEVELING.}

1. Daar mag sekere punte van verskil tussen die Gereformeerde Ekumeniese Sinode en die Nederduitsch Hervormde Kerk van Afrika wees, maar oor die dinge wat vir ons op die verskillende terreine baie belangrik is, stem ons saam en daarom wil ek pleit vir 'n simpatieke aandag.

2. Daar die stelling ,in ons isolasie lê ons krag" vandag nie meer opgaan nie, kan ons nie langer buite enige ekumeniese verband staan nie: daarom is ek van oortuiging dat ons by hierdie ekumeniese liggaam aansluiting moet soek.

3. Die Gereformeerde Ekumeniese Sinode tree slegs adviserend op en haar besluite kan vir die verskillende Kerke slegs bindend wees nadat die verskillende sinodes van die verskillende Kerke die besluite aanvaar het. Daar bestaan dus geen gevaar dat die Gereformeerde Ekumeniese Sinode sy besluite op die lidkerke afdwing nie.

4. Alleen Kerke van protestantse belydenis kan lid van die Sinode word: dus alleen Kerke wat die belydenisskrifte in die basis-formule genoem, onderskryf. 